\title{
Novel methodologies for assessing omega-3 fatty acid status - a systematic review
}

\author{
Mario Klingler and Berthold Koletzko* \\ University of Munich Medical Center, Dr. von Hauner Children's Hospital, Div. Metabolic and Nutritional Medicine, \\ München, Germany
}

\begin{abstract}
Over the last few decades $n-3$ long chain polyunsaturated fatty acid status became of special interest for scientists. Biochemical measures on the $n$ - 3 fatty acid status vary depending on body compartment assessed and measures chosen. Plasma phospholipids and red blood cell membrane phospholipids are mainly used as $n-3$ fatty acid status marker. The conventional analysis of phospholipid fatty acids involves lipid extraction and consecutive chromatographic separation of phospholipids from other lipid fractions, which is time-consuming and costly. In recent years, different investigators have tried to overcome these limitations by using other biological markers or by modifying the analytical procedures used to assess $n-3$ fatty acid status. The aim of this systematic review was to provide an overview on these novel analytical methods developed for the fatty acid quantification by gas chromatography, highlights the methodological limitations, and discusses advantages or disadvantages of the biological markers used. Seventeen papers were identified that fulfilled the inclusion criteria. New opportunities arise from sensitive and precise high-throughput methodologies for assessment of plasma total lipid and plasma glycerophospholipid fatty acids, as well as cheek cell fatty acid composition.
\end{abstract}

Key words: Docosahexaenoic acid: eicosapentaenoic acid: omega-3 status: gas chromatography: biological marker: FAME preparation

Diet and metabolic turnover determine an individual's fatty acid status ${ }^{1}$. Studies on the dietary fatty acid intake often rely on food frequency questionnaires. The data obtained provide information about the type of diet consumed, but in general, they are improper as accurate measurement of the individual fatty acid status. Various biological compartments, such as whole blood, blood cells, plasma, and adipose tissue have been used to determine the individual fatty acid status reflecting the dietary fat intake $e^{2 ; 3}$. The fatty acid status can also be used as marker for malnutrition, for example, a deficiency in linoleic acid can be assessed by comparing the ratio between mead acid (C20:3n-9) and arachidonic acid (ARA) levels ${ }^{4}$.

Alterations in fatty acid status are also found in certain diseases, such as cystic fibrosis or gestational diabetes mellitus ${ }^{5-7}$.

Over the last few decades the $n-3$ long chain polyunsaturated fatty acid (LC-PUFA) status became of special interest for scientists, focusing on eicosapentaenoic acid (EPA) and docosahexaenoic acid (DHA). These fatty acids have been investigated extensively in cross-sectional or longitudinal observation studies and intervention trials to determine their effect on growth and development of pre-term and full-term infants ${ }^{8-11}$, the outcome of pregnancy ${ }^{12-14}$, and the prevention or treatment of diseases, such as attention deficit hyperactivity disorder ${ }^{15}$, cardiovascular diseases $^{16 ; 17}$, cancer $^{18-20}$, depression $^{21-23}$ and post-partum depression ${ }^{24}$, Crohn's disease ${ }^{25}$, asthma ${ }^{26}$, cystic fibrosis $^{27}$, dementia ${ }^{28}$ and Alzheimer disease ${ }^{29}$.

All these studies relate analysed $n-3$ fatty acids levels to defined clinical outcome parameters, however, there is no agreed standard procedure for fatty acid analysis. Various analytical methods are published to determine the $n-3$ fatty acid status of an individual. Most of these methods are timeconsuming, require a great amount of handling and are costly. Moreover, the applied techniques often use invasive sampling, which may limit their use in studies involving infants and young children, or subjects with inaccessible veins. This will impede the recruitment of volunteers for studies, especially if multiple blood sampling is necessary.

In recent years, researchers have tried to overcome these limitations by using different biological markers or by adapting the analytical procedures to assess the $n$ - 3 fatty acid status. This systematic review was conducted to identify

Abbreviations: ARA, arachidonic acid; BHT, butylhydroxytoluene; CE, cholesterol esters; DHA, docosahexaenoic acid; EPA, eicosapentaenoic acid; FAME, fatty acid methyl esters; LC-PUFA, long chain polyunsaturated fatty acids; NEFA, non-esterified fatty acids; PL, phospholipids; RBC, red blood cells; SFA, saturated fatty acids; SP, sphingomyeline; TAG, triacylglycerides(182 words).

* Corresponding author: Berthold Koletzko, fax +49-89-5160-7742, email office.koletzko@med.uni-muenchen.de 
methods, which exclude traditional lipid extraction and chromatographic lipid class separation. It will highlight the advantages and disadvantages of these novel analytical methods developed for the fatty acid quantification by gas chromatography.

\section{Methods}

A systematic literature research of articles from 1990 onwards was conducted in April 2011. The search comprised the databases Medline and EmBASE. Further studies were identified through hand searching of original articles on subjects found by the computerised search.

\section{Search terms}

The following search terms were used to identify relevant scientific articles in the Medline and EmBASE databases: analysis, biological marker, blood, blood drop, blood spot, cheek cell OR cheek cells, direct, dried blood, EPA + DHA, fatty acid OR fatty acids, fatty acid status, gas chromatography, glycerophospholipids, high-throughput, omega-3 fatty acids, rapid method, total lipids, transesterification, and whole blood. Studies were limited to those executed with humans and written in English from January 1990 and April 2011, with the exception of the study of Lepage and Roy conducted in $1986^{30}$.

\section{Selection of studies}

Articles reporting total fatty acid contents in blood compartments or cheek cells were included in the survey. Exclusion criteria were lipid extraction from specimens, the chromatographic separation of lipids, i.e. thin layer chromatography or solid phase extraction, and multiple steps for the esterification of fatty acids. Furthermore, articles which did not fully describe the method but referred to other authors were also excluded.

The initial screening of the articles was based on the title and the abstract. Abstracts which did not meet the inclusion criteria were rejected. Articles that were thought to be adequate for this review or whose eligibility was unclear were obtained as full text. The selected articles were evaluated according the inclusion and exclusion criteria. In addition, these articles were hand searched for further relevant publications.

\section{Results}

A total of 419 abstracts were identified from the database search. After careful screening, 61 full text articles were obtained, reviewed and analysed. Of these, only 17 met the inclusion criteria (Fig. 1). Two authors used the original method of Lepage and Roy, thus 15 different methods were evaluated and summarised in Table 1. In this table relevant aspects regarding sampling procedure, storage of fresh samples, methodological procedure, validation, and pro and cons of the method were described.

\section{Findings}

In general, the analysis of the fatty acid profile in biological samples often includes the extraction of crude lipids ${ }^{31-33}$, the separation of lipid fractions by using thin layer chromatography $y^{34 ; 35}$ or solid phase extraction ${ }^{36-39}$, the fatty acid methyl ester (FAME) synthesis ${ }^{40}$ and the chromatographic quantification $^{41}$ (Fig. 2A). These procedures are time-consuming, costly and require a great amount of handling. The following section reviews novel approaches for the fatty acid status marker assessment. The presented methods exclude traditional lipid extraction and chromatographic lipid class separation. Most of these methods have been validated in comparison to different reference methods or have been applied in various studies.

\section{Plasma Total Lipids}

In 1986, Lepage and Roy developed a rapid method for the fatty acid analysis of total lipids in plasma (Fig. 2 B) ${ }^{30}$. Solvents (methanol-benzene 4:1) and internal standard were directly added to a small plasma aliquot. Acetyl chloride was used for FAME synthesis $\left(100^{\circ} \mathrm{C}, 60 \mathrm{~min}\right)$. The sample was neutralised with potash and the upper benzene phase was directly injected into GC for fatty acid analysis. Later, the method was applied to determine an essential fatty acid deficiency in patients with cystic fibrosis ${ }^{42}$, or for the monitoring of DHA plasma contents in patients with a disorder of peroxisome biogenesis ${ }^{43}$. The method was also be applied for other biological samples, i.e. breast milk ${ }^{44}$ or red blood cells (RBC) and fibroblasts ${ }^{43 ; 45}$

Recently, this method was further optimised for the robotics-amenable analysis of plasma fatty acids ${ }^{46}$. In this process, benzene was replaced by methanol and toluene. A stock solution was prepared containing these solvents, internal standard and acetyl chloride. The solution was added to plasma and heated to $80^{\circ} \mathrm{C}$ in an open tube for $120 \mathrm{~min}$. Every $25 \mathrm{~min}$ a second stock solution without internal standard was added to replace the evaporated solvents. FAME were extracted with hexane without neutralising the reaction. The robotic variant was validated against the method of Lepage and Roy. Low coefficients of variation (CV) were indicated for all fatty acids of both procedures. The authors claimed that fatty acid concentrations were similar irrespective of the method applied, although no statistical analysis was provided. In a further publication the semi-automated method was described in more detail ${ }^{47}$. The analysis of up to 200 samples per day is predicted, but limitations of data analysis have to be overcome before applying the method in large clinical trials.

The modified method of Lepage and Roy was used by another author for the determination of changes in plasma total fatty acids after fish oil supplementation ${ }^{48}$.

Plasma total lipids have also been analysed with an oncolumn methylation procedure, which was recently described by Akoto et $a l^{49}$. A small plasma volume was placed in an insert inside a capped liner. The plasma sample was dried for $3 \mathrm{~min}$ before trimethylsulfonium hydroxide was added. The mixture was incubated for $15 \mathrm{~min}$ and dried under vacuum. After adding an internal standard the liner was heated from $40^{\circ} \mathrm{C}$ to $280^{\circ} \mathrm{C}$ to effect thermally assisted methylation. The procedure indicated a good repeatability and was also tested for whole blood fatty acids. However, a comparison 


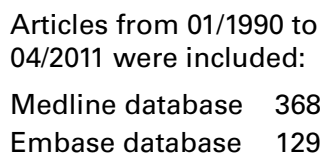

Fig. 1. Flowchart of articles

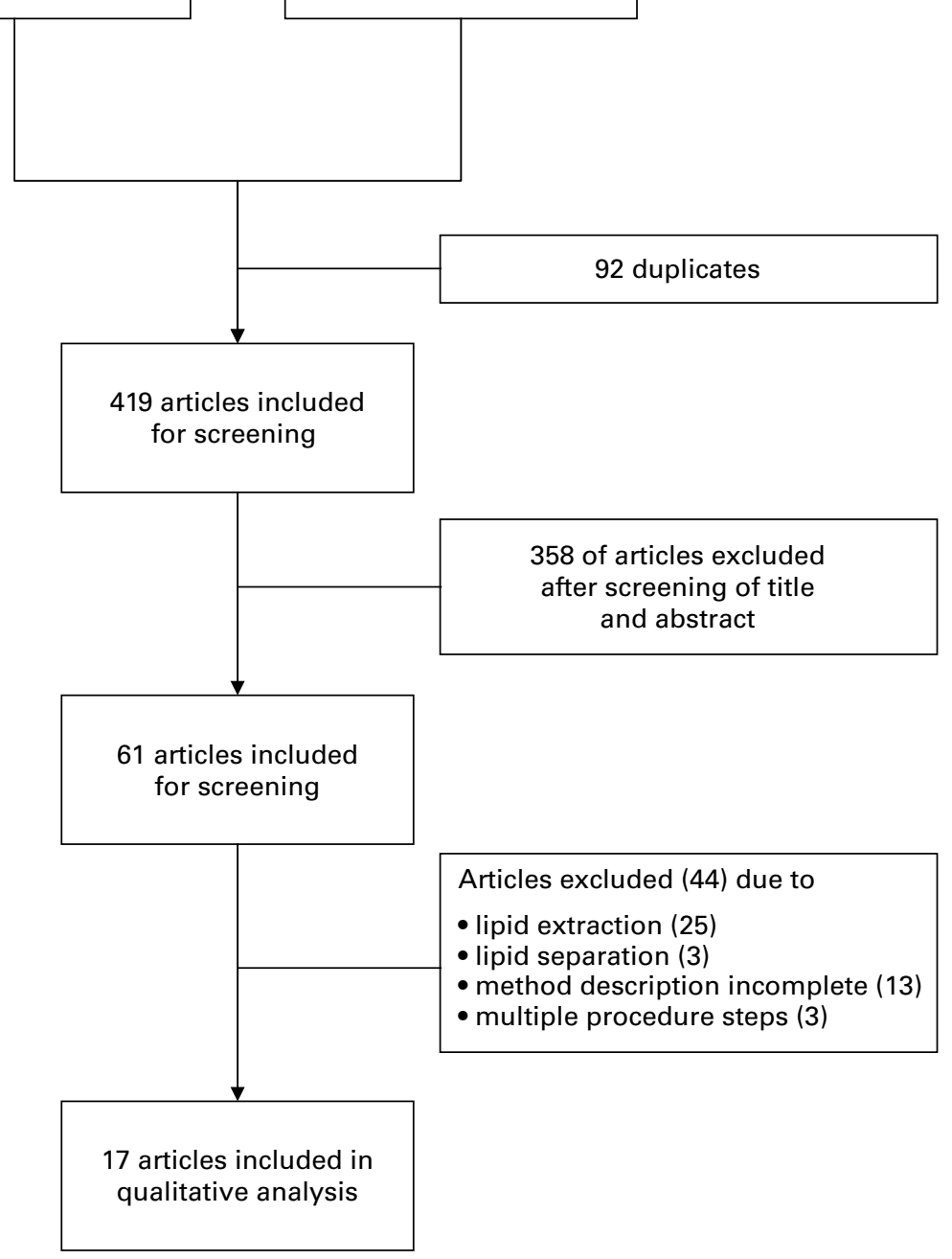

Articles included through Hand search 14 with a conventional method indicated different percentages for almost all fatty acids, particularly $n-3$ fatty acids, although the authors claim that saturated fatty acids (SFA), monounsaturated fatty acids, and PUFA contents are similar.

A simplified in-situ derivatisation method was published by Glaser et al. for a high-throughput fatty acid analysis of total plasma lipids ${ }^{50}$. Internal standard and methanolic $\mathrm{HCl}$ (+ butylhydroxytoluene; $\mathrm{BHT}$ ) were added to plasma aliquots and incubated for $45 \mathrm{~min}$ at $85^{\circ} \mathrm{C}$. After cooling of the samples, FAME were extracted by hexane without neutralisation step. Intra-assay reproducibility was determined by repeated aliquot measurements. Low CVs were observed for fatty acids contributing more than $1 \%$ to total fatty acids. Storage of FAME derivatives at $-20^{\circ} \mathrm{C}$ for 4 weeks did not affect the fatty acid pattern. Compared to an established laboratory standard procedure, the in-situ transesterification method revealed higher plasma total fatty acid concentrations. Although the differences were significant, both methods indicated similar FA proportions.

A similar method was published by Takemoto et al. for the screening of peroxisomal disorders ${ }^{51}$. The settings for the FAME synthesis with $\mathrm{HCl}$ were different $\left(100^{\circ} \mathrm{C}, 120 \mathrm{~min}\right)$, but the resulting methyl ester were also extracted with hexane without neutralisation step. The intra-assay precision for most of the analysed fatty acids was very good, except for very long saturated fatty acids $>24$ C-atoms.

\section{Whole Blood Total lipids}

The fatty acid status of whole blood total lipids is rarely described in literature. Recently, the fatty acid analysis of dried blood on filter paper obtained by finger prick was introduced $^{52-54}$. Marangoni et al. developed a simple method, which abandoned the separation of blood cells and 
C
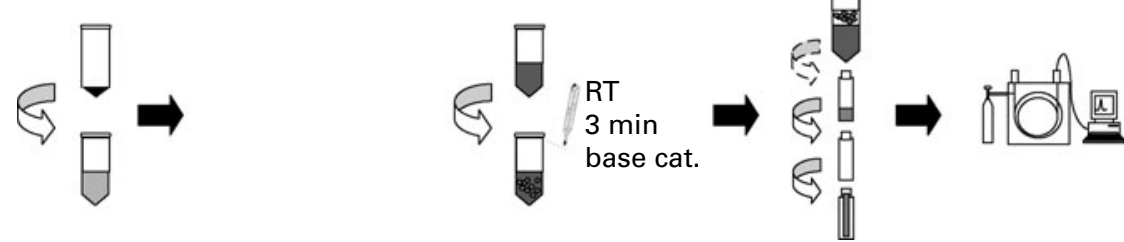

Fig. 2. Schematic overview of analytical procedures for gas chromatographic fatty acid quantification. A: conventional procedure for the analysis of individual lipid fractions, B: procedure for whole blood, plasma or RBC total lipids, C: procedure for plasma or cheek cell glycerophospholipids. GC: gas chromatographic, TLC: thin layer chromatography, SPE: solid phase extraction, cat.: catalysed, RT: room temperature

plasma $^{54}$. Capillary blood was obtained by a finger prick and collected on filter paper. The paper was treated with BHT, if the storage period exceeded more than 14 days. For FAME synthesis a strip of filter paper $\left(1 \mathrm{~cm}^{2}\right)$, containing approximately 15 to $75 \mu$ l whole blood, was submerged directly in methanolic $\mathrm{HCl}$. Subsequently, water and $\mathrm{KCl}$ were added before extracting FAME with hexane. The results have not been compared with a reference method, but repeated analyses of samples indicated a high reproducibility. The method was validated in a study with volunteers categorised in low vs. high fish consumer or low vs. high meat consumers. Outcome of this study was that the different dietary habits were reflected in whole blood DHA or ARA contents. This method was later applied in various clinical studies to assess the fatty acid status of infants in relation to intrauterine growth or maternal smoking habits and changes in the fatty acid status in patient with cystic fibrosis $7 ; 55 ; 56$

The group of Bailey-Hall et al. also used dried blood samples for the evaluation of PUFA levels in humans ${ }^{53}$. Filter paper was treated with BHT prior to blood collection. Blood spots were dried over night and stored for 1 day at $-80^{\circ} \mathrm{C}$ before further processing. Samples of the filter paper and internal standard were transferred into glass tubes, saponified with $\mathrm{NaOH}$ and subsequently transesterified with methanolic $\mathrm{BF}_{3}$. Details for FAME extraction were not provided. The results of capillary blood obtained by finger prick were compared against plasma PL and RBC total lipids. The majority of fatty acids (mol \%) from plasma PL, RBC, and capillary whole blood was different with significantly lower DHA and ARA contents in the latter compartment. Correlation analysis showed strong relationships for DHA, EPA and docosapentaenoic acid (DPA) and relatively low, but still significant relationships for ARA in all 3 compartments. This method was used in an intervention trial to evaluate the effect of DHA supplements on cognitive functions in healthy pre-school children ${ }^{57}$.

A further procedure for the evaluation of capillary whole blood fatty acids was provided by Armstrong et al. ${ }^{52}$.Capillary blood collected by puncturing the fingertip was dropped on chromatography paper. The treatment of the paper with antioxidants was abandoned because of the immediate sample preparation after collection. For the transesterification procedure of whole blood fatty acids, a strip of $0.5 \times 1 \mathrm{~cm}$ was submerged in methanolic $\mathrm{BF}_{3}$ plus hexane containing BHT, and placed in a commercial microwave oven for $45 \mathrm{sec}$. Additional hexane was added to extract the FAME. The results of the microwave treatment were compared to a conventional method including lipid extraction and acid catalysed FAME derivatisation $\left(\mathrm{BF}_{3} / \mathrm{MeOH}, 90^{\circ} \mathrm{C}, 60 \mathrm{~min}\right)$. It was shown that the microwave supported transesterification process resulted in 2-fold higher stearic acid levels (mol \%) and significantly lower oleic acid and ARA levels. Significant differences between $n$ - 3 fatty acids were not observed. The authors concluded that the use of microwave heating for FAME synthesis has potential, but additional modifications and testing are required. Further applications of the described method are not known.

A further method for the analysis of whole blood total lipids was described by Bicalho et al. ${ }^{58}$. Blood (35-60 $\mu \mathrm{g}$ ) was collected with a capillary containing citric acid, transferred in a reaction vial and directly transesterified with acetyl chloride 
Table 1. Overview on novel methodological approaches for the assessment of $n-3$ fatty acid status

\begin{tabular}{|c|c|c|c|c|c|c|c|}
\hline & Storage $^{1}$ & Sampling & $\begin{array}{l}\text { Transesterification } \\
\text { reagents and settings }\end{array}$ & $\begin{array}{l}\text { FAME } \\
\text { extraction }\end{array}$ & Validation & Pros $^{2}$ & Cons \\
\hline \multicolumn{8}{|c|}{ Whole blood total lipids } \\
\hline $\begin{array}{l}\text { Armstrong } \\
\text { et al.(2008) }\end{array}$ & $\begin{array}{l}\text { processed } \\
\text { immediately }\end{array}$ & $\begin{array}{l}\text { Volume n/d. blood } \\
\text { obtained from finger } \\
\text { prick, dried blood on } \\
\text { chromatography paper }\end{array}$ & $\begin{array}{l}\mathrm{BF}_{3} \text { in methanol }(14 \%)+ \\
\text { hexane short term } \\
\text { microwave heating for } \\
45 \mathrm{sec}\end{array}$ & hexane & $\begin{array}{l}\text { comparison with reference } \\
\text { method applied to venous } \\
\text { blood, (Folch extraction, } \\
\mathrm{BF}_{3} \text { ) }\end{array}$ & $\begin{array}{l}\text { Advantages of blood } \\
\text { sampling by finger } \\
\text { prick }^{3}, \text { very short } \\
\text { processing time }\end{array}$ & $\begin{array}{l}\text { loss of n-3 during storage } \\
\text { depending on postpran- } \\
\text { dial state }{ }^{5} \text {, significantly } \\
\text { lower estimates of } \\
\text { MUFA and PUFA com- } \\
\text { pared to conventional } \\
\text { method }\end{array}$ \\
\hline $\begin{array}{l}\text { Akoto et al. } \\
\quad(2008)\end{array}$ & $\begin{array}{l}\text { processed } \\
\text { immediately } \\
\text { or stored at } \\
4^{\circ} \mathrm{C}+\mathrm{BHT} \\
\text { in ethanol }\end{array}$ & $\begin{array}{l}2 \mu \mathrm{l} \text { whole blood or } \\
\text { plasma, sampling } \mathrm{n} / \mathrm{d}\end{array}$ & $\begin{array}{l}\text { trimethylsulfonium hydrox- } \\
\text { ide solution in methanol } \\
(5 \mathrm{mM}), 15 \mathrm{~min} \text { incu- } \\
\text { bation; vacuum for } 45 \\
\text { sec, heated from } \\
40^{\circ}-280^{\circ} \mathrm{C} \text { at } 16^{\circ} \mathrm{C} / \mathrm{sec}\end{array}$ & $\mathrm{n} / \mathrm{a}$ & $\begin{array}{l}\text { comparison with reference } \\
\text { method applied to whole } \\
\text { blood and plasma (sodium } \\
\text { methylate, } \mathrm{BF}_{3} \text { ) }\end{array}$ & $\begin{array}{l}\text { on column transesteri- } \\
\text { fication }\end{array}$ & $\begin{array}{l}\text { DHA + EPA values } \\
\text { differed to reference- } \\
\text { method }\end{array}$ \\
\hline $\begin{array}{l}\text { Bailey-Hall } \\
\text { et al. (2007) }\end{array}$ & $\begin{array}{l}-80^{\circ} \mathrm{C} \text { for } 1 \mathrm{~d} \\
\text { filter treated } \\
\text { with BHT }\end{array}$ & $\begin{array}{l}\text { Volume n/d. blood } \\
\text { obtained from finger } \\
\text { prick, dried blood on } \\
\text { chromatography paper }\end{array}$ & $\begin{array}{l}\mathrm{NaOH}+\mathrm{BF}_{3} \text { in methanol } \\
(14 \%) \text {; heated to } 100^{\circ} \mathrm{C} \\
\text { for } 30 \text { min }\end{array}$ & hexane & $\begin{array}{l}\text { comparison with reference } \\
\text { method applied to RBC and } \\
\text { plasma, (Bligh \& Dyer or } \\
\text { Folch extraction, } \mathrm{BF}_{3} \text { ) }\end{array}$ & $\begin{array}{l}\text { Advantages of blood } \\
\text { sampling by finger }_{\text {prick }^{3}}\end{array}$ & $\begin{array}{l}\text { loss of } n-3 \text { during stora- } \\
\text { ge }{ }^{4} \text {,depending on } \\
\text { postprandial state }\end{array}$ \\
\hline $\begin{array}{l}\text { Bicalho et al. } \\
\quad(2008)\end{array}$ & $\begin{array}{l}\text { processed } \\
\text { immediately }\end{array}$ & $\begin{array}{l}35-60 \mu l \text { blood from finger } \\
\text { prick, collected in } \\
\text { capillary coated with } \\
\text { citric acid /methanol }\end{array}$ & $\begin{array}{l}\text { acetyl chloride in methanol } \\
(5 \%) \text {; heated at } 90^{\circ} \mathrm{C} \\
\text { for } 30 \mathrm{~min}\end{array}$ & hexane & $\begin{array}{l}\mathrm{n} / \mathrm{d} \text {, method applied to create } \\
\text { a methyl ester database for } \\
\text { lipid profiling }\end{array}$ & $\begin{array}{l}\text { Advantages of blood } \\
\text { sampling by finger }_{\text {prick }^{3}}\end{array}$ & $\begin{array}{l}\text { depending on postprandial } \\
\text { state }^{5}\end{array}$ \\
\hline $\begin{array}{l}\text { Marangoni } \\
\text { et al. (2004) }\end{array}$ & $\begin{array}{c}4^{\circ} \mathrm{C} \text {, filter trea- } \\
\text { ted with BHT } \\
(50 \mu \mathrm{g} \text { in } 10 \\
\mu \mathrm{l} \text { methanol })\end{array}$ & $\begin{array}{l}15-75 \mu \text { l blood obtained } \\
\text { from finger prick, dried } \\
\text { blood on chromatog- } \\
\text { raphy paper }\end{array}$ & $\begin{array}{l}3 \mathrm{~N} \text { methanolic } \mathrm{HCl} \text {; } \\
\text { heated at } 90^{\circ} \mathrm{C} \text { for } \\
60 \mathrm{~min}\end{array}$ & hexane & $\begin{array}{l}\text { Inter-Assay }<3 \% \text { for all ana- } \\
\text { lysed FA Intra-Assay }<4 \% \\
\text { for all analysed FA }\end{array}$ & $\begin{array}{l}\text { Advantages of blood } \\
\text { sampling by finger } \\
\text { prick }{ }^{3} \text { method indicates } \\
\text { a good repeatability }\end{array}$ & $\begin{array}{l}\text { loss of } n-3 \text { during stora- } \\
\text { ge } e^{4} \text { depending on } \\
\text { postprandial state }\end{array}$ \\
\hline $\begin{array}{r}\text { Min et al. } \\
\text { (2011) }\end{array}$ & $\begin{array}{l}4^{\circ} \mathrm{C} \text {, filter trea- } \\
\text { ted with } 80 \\
\mu l \mathrm{BHT} \\
\text { solution }\end{array}$ & $\begin{array}{l}20-40 \mu l \text { blood obtained } \\
\text { from finger prick, dried } \\
\text { blood on filter paper } \\
\text { (Fluka dipstick) }\end{array}$ & $\begin{array}{l}\text { acetyl chloride in methanol } \\
(15 \%) \text {; heated at } 70^{\circ} \mathrm{C} \\
\text { for } 180 \mathrm{~min}\end{array}$ & $\begin{array}{l}\text { sodium chlor- } \\
\text { ide }(5 \%)+ \\
\text { petrol spirit } \\
(2: 1)\end{array}$ & $\begin{array}{l}\text { comparison with reference } \\
\text { method applied to venous } \\
\text { blood, (Folch extraction, } \\
\text { acetyl } \\
\text { chloride) }\end{array}$ & $\begin{array}{l}\text { Advantages of blood } \\
\text { sampling by finger }_{\text {prick }^{3}}\end{array}$ & $\begin{array}{l}\text { loss of } n-3 \text { during stora- } \\
\text { ge }^{4} \text {,depending on } \\
\text { postprandial state } \\
\text { of } \text {,time } \\
\text { FAME synthesis }\end{array}$ \\
\hline \multicolumn{8}{|l|}{ RBC total lipids } \\
\hline $\begin{array}{l}\text { Araujo et al. } \\
\text { (2008) }\end{array}$ & $n / d$ & $\begin{array}{l}\text { sampling not described, } 50 \\
\mu l \text { RBC used for } \\
\text { analysis }\end{array}$ & $\begin{array}{l}\mathrm{BF}_{3} \text { in methanol }(20 \%) \text { or } \\
\mathrm{BCl}_{3} \text { in methanol }(14 \%) \text {; } \\
\text { heated at } 100^{\circ} \mathrm{C} \text { for } \\
60 \text { min }\end{array}$ & hexane & $\begin{array}{l}\text { total variance in average } \\
3.2 \% \text {,comparison with refer- } \\
\text { ence method }\end{array}$ & $\begin{array}{l}\mathrm{BF}_{3} \text { or } \mathrm{BCl}_{3} \text { indicate no } \\
\text { differences in } \\
\text { transesterification } \\
\text { efficiency }\end{array}$ & \\
\hline $\begin{array}{l}\text { Block et al. } \\
\quad(2008)\end{array}$ & $n / d$ & $\begin{array}{l}\text { sampling not described, } \\
250 \mu \mathrm{l} \text { RBC membrane } \\
\text { used for analysis }\end{array}$ & $\begin{array}{l}\mathrm{BF}_{3} \text { in methanol }(14 \%) \\
\text { heated at } 100^{\circ} \mathrm{C} \text { for } \\
10 \mathrm{~min}\end{array}$ & $\begin{array}{l}\text { water-hexane } \\
\quad(1: 1)\end{array}$ & $\begin{array}{l}\text { CV for EPA + DHA }<5 \% \text {, } \\
\text { method applied to measure } \\
\text { the omega-3 index in } \\
\text { humans }\end{array}$ & $\begin{array}{l}\text { specific for GPL and } \\
\text { non-esterified fatty acids }\end{array}$ & $\begin{array}{l}\text { strict derivatisation pro- } \\
\text { cedure has to be } \\
\text { followed as FAME } \\
\text { synthesis of lipid } \\
\text { classes is time depen- } \\
\text { dent, only limited } \\
\text { information available to } \\
\text { calculate the omega-3 } \\
\text { index }\end{array}$ \\
\hline \multicolumn{8}{|c|}{ Plasma total lipids } \\
\hline $\begin{array}{l}\text { Garg et al. } \\
(2006)\end{array}$ & $n / d$ & $\begin{array}{l}\text { sampling not described, } \\
100 \mu \mathrm{l} \text { plasma used for } \\
\text { analysis }\end{array}$ & $\begin{array}{l}\text { methanol-toluene }(4: 1)+ \\
\text { acetyl chloride; heated } \\
\text { to } 100^{\circ} \mathrm{C} \text { for } 60 \mathrm{~min}, \\
\text { neutralised with potass- } \\
\text { ium carbonate }\end{array}$ & toluene & $\begin{array}{l}\mathrm{n} / \mathrm{d} \text {, method applied to analyse } \\
\text { plasma total lipids of heart } \\
\text { patients }\end{array}$ & $\begin{array}{l}\text { benzene replaced by the } \\
\text { less toxic toluene }\end{array}$ & $\begin{array}{l}\text { depending on postprandial } \\
\text { state }^{5}\end{array}$ \\
\hline
\end{tabular}


NS British Journal of Nutrition

\begin{tabular}{|c|c|c|c|c|c|c|c|}
\hline & Storage $^{1}$ & Sampling & $\begin{array}{l}\text { Transesterification } \\
\text { reagents and settings }\end{array}$ & $\begin{array}{l}\text { FAME } \\
\text { extraction }\end{array}$ & Validation & Pros $^{2}$ & Cons \\
\hline $\begin{array}{l}\text { Glaser et al. } \\
\quad(2010 \mathrm{a})\end{array}$ & $n / d$ & $\begin{array}{l}\text { sampling not described, } \\
100 \mu l \text { plasma used for } \\
\text { analysis }\end{array}$ & $\begin{array}{l}3 \mathrm{~N} \text { methanolic } \mathrm{HCl} \text {; } \\
\text { heated at } 85^{\circ} \mathrm{C} \text { for } \\
45 \mathrm{~min}\end{array}$ & hexane & $\begin{array}{l}\text { Intra-Assay }<8 \% \text { for all ana- } \\
\text { lysed FA, comparison with } \\
\text { reference method applied to } \\
\text { plasma (Folch extraction, } \\
\mathrm{HCl} \text { ) }\end{array}$ & $\begin{array}{l}\text { method indicates a good } \\
\text { repeatability }\end{array}$ & $\begin{array}{l}\text { depending on postprandial } \\
\text { state }^{5}\end{array}$ \\
\hline $\begin{array}{l}\text { Lepage and } \\
\text { Roy (1986) }\end{array}$ & $\begin{array}{l}\text { processed } \\
\text { immediately }\end{array}$ & $\begin{array}{l}\text { sampling not described, } \\
100 \mu \mathrm{l} \text { plasma used for } \\
\text { analysis }\end{array}$ & $\begin{array}{l}\text { methanol-benzene }(4: 1)+ \\
\text { acetyl chloride; heated } \\
\text { to } 100^{\circ} \mathrm{C} \text { for } 60 \mathrm{~min}, \\
\text { neutralised with potass- } \\
\text { ium carbonate }\end{array}$ & benzene & $\begin{array}{l}\text { recovery rates of standards, } \\
\text { comparison with reference } \\
\text { method (Folch extraction) }\end{array}$ & $\begin{array}{l}\text { method applicable for dif- } \\
\text { ferentbiological } \\
\text { samples, }\end{array}$ & $\begin{array}{l}\text { depending on postprandial } \\
\text { state }^{5} \text { toxicity of benzene }\end{array}$ \\
\hline $\begin{array}{l}\text { Masood et al. } \\
\quad \text { (2005), } \\
\text { Masood et al. } \\
\text { (2008) }\end{array}$ & $\begin{array}{l}-80^{\circ} \mathrm{C} \text {, plasma } \\
\text { aliquots }\end{array}$ & $\begin{array}{l}\text { venipuncture, } 50 \mu l \\
\text { plasma used for anal- } \\
\text { ysis }\end{array}$ & $\begin{array}{l}\text { methanol }+ \text { acetyl chlor- } \\
\text { ide; heated to } 100^{\circ} \mathrm{C} \text { for } \\
60 \mathrm{~min}\end{array}$ & hexane & $\begin{array}{l}\text { Intra-Assay }<8 \% \text { for all ana- } \\
\text { lysed FA, comparison with } \\
\text { the method of Lepage \& } \\
\text { Roy }\end{array}$ & $\begin{array}{l}\text { semi-automated analysis } \\
\text { of FA, high-throughput } \\
\text { of samples, }\end{array}$ & $\begin{array}{l}\text { depending on postprandial } \\
\text { state }^{5}\end{array}$ \\
\hline $\begin{array}{l}\text { Takemoto et al. } \\
\text { (2003) }\end{array}$ & $\begin{array}{l}-20^{\circ} \mathrm{C} \text {, plasma } \\
\text { or serum }\end{array}$ & $\begin{array}{l}\text { sampling not described, } \\
100 \mu \text { l plasma or serum } \\
\text { used for analysis }\end{array}$ & $\begin{array}{l}\text { methanolic } \mathrm{HCL}(5 \%) \\
\text { heated at } 100^{\circ} \mathrm{C} \text { for } \\
120 \mathrm{~min}\end{array}$ & hexane & $\begin{array}{l}\text { Intra-Assay }<4.3 \% \text { for all } \\
\text { analysed FA, except for FA } \\
\text { with }>24 \text { C-atoms }\end{array}$ & $\begin{array}{l}\text { method indicates a good } \\
\text { repeatability }\end{array}$ & $\begin{array}{l}\text { depending on postprandial } \\
\text { state }^{5}\end{array}$ \\
\hline \multicolumn{8}{|c|}{ Plasma glycerophospholipids } \\
\hline $\begin{array}{l}\text { Glaser et al. } \\
\quad(2010 \mathrm{~b})\end{array}$ & $-20^{\circ} \mathrm{C}$ & $\begin{array}{l}\text { sampling not described, } \\
100 \mu \mathrm{l} \text { plasma used for } \\
\text { analysis }\end{array}$ & $\begin{array}{l}\text { methanol + sodium meth- } \\
\text { oxide in methanol } \\
(25 \%) \text {; incubated at RT } \\
\text { for } 3 \mathrm{~min}\end{array}$ & hexane & $\begin{array}{l}\text { Intra-Assay }<4 \% \text { for all ana- } \\
\text { lysed FAlntra-Assay }<11 \% \\
\text { for all analysed FA, com- } \\
\text { parison with reference } \\
\text { method for PL (Folch } \\
\text { extraction, TLC, HCl) }\end{array}$ & $\begin{array}{l}\text { specific for GPL FA acids, } \\
\text { FAME synthesis at } \\
\text { room temperature short } \\
\text { processing time high- } \\
\text { throughput of samples } \\
\text { possibility for automated } \\
\text { FA analysis }\end{array}$ & $\begin{array}{l}\text { SP or SFA with }>20 \\
\text { C-atoms are not } \\
\text { detected with this } \\
\text { method }\end{array}$ \\
\hline \multicolumn{8}{|c|}{ Cheek cell glycerophospholipids } \\
\hline $\begin{array}{l}\text { Klingler et al. } \\
\text { (2011) }\end{array}$ & $\begin{array}{l}\text { processed } \\
\text { immediately }\end{array}$ & $\begin{array}{l}\text { swab of the inner side of } \\
\text { both cheeks, } 100,000- \\
850,000 \text { cells used for } \\
\text { analysis }\end{array}$ & $\begin{array}{l}\text { methanol + sodium meth- } \\
\text { oxide in methanol } \\
\text { ( } 25 \%) \text {; incubated at RT } \\
\text { for } 4 \mathrm{~min}\end{array}$ & hexane & $\begin{array}{l}\text { Intra-Assay }<10 \% \text { for all } \\
\text { analysed FAlnter-Assay } \\
<14.2 \% \text { for all analysed } \\
\text { FA, comparison with plasma } \\
\text { GPL }\end{array}$ & $\begin{array}{l}\text { non-invasive sampling } \\
\text { specific for GPL FA } \\
\text { acids, FAME synthesis } \\
\text { at room temperature } \\
\text { short processing time } \\
\text { high-throughput of } \\
\text { samples possibility for } \\
\text { automated FA analysis }\end{array}$ & $\begin{array}{l}\text { SP or SFA with }>20 \\
\text { C-atoms are not } \\
\text { detected with this } \\
\text { method, sample size } \\
\text { varies,samples might } \\
\text { be lost if cell number } \\
\text { is too low }\end{array}$ \\
\hline
\end{tabular}

n/d: not described, FA: fatty acids, MUFA: monounsaturated FA

1 Storage of samples prior to analysis

2 Advantages such as time and cost savings, reduced solvent and equipment usage, enhanced through-put of samples and low sample volume needed for analysis apply to all the methods presented in this table

3 Advantages of blood sampling by finger prick: minimal invasive sampling; no venipuncture required for blood sampling; samples can be taken independently to location of a laboratory; sample preparation, storage and shipment

save costs; sample storage requires much less space
4 Losses of $n-3$ LC-PUFA observed during storage at room temperature or at $4^{\circ} \mathrm{C}$, although filter paper was treated with $\mathrm{BHT}$

5 TAG and CE lipid levels in blood are rapidly affected after a meal. Strict sampling conditions such as overnight fasting are required (not applicable in infants) 
in methanol $\left(90^{\circ} \mathrm{C}, 30 \mathrm{~min}\right)$. The resulting FAME were extracted with hexane. The methyl ester were analysed by mass spectrometry, thus more than 80 fatty acids were detected. The aim of the study was to create a FAME database for lipid profiling, thus data on methodological precision or accuracy are not presented.

Another study group used a similar method for the synthesis of FAME in dried blood on filter paper. A higher concentration of acetyl chloride in methanol was chosen for the methylation of fatty acids with different incubation parameters $\left(70^{\circ} \mathrm{C}\right.$, $180 \mathrm{~min})^{59}$. After the derivatisation FAME were extracted with petrol spirit. Precision and accuracy data are not presented in this paper, but data were compared to a conventional method (Lipid extraction by Folch, same derivatisation procedure). The data indicate that slightly higher proportions of SFA and monounsaturated fatty acids and lower proportions of $n-3$ and $n-6$ PUFA are obtained, although no statistical analysed was conducted.

\section{RBC Total Lipids}

One of the most recognised findings in terms of $n$ - 3 LC-PUFA research over the last decade was the invention of the 'omega3 -index' ${ }^{60}$. The omega-3-index basically describes the proportional EPA+DHA content of total fatty acids in RBC, although the methodological approach does not capture the total fatty acid profile of all RBC lipid fractions ${ }^{61}$. A detailed description of the method was not provided in the article of Harris and von Schacky ${ }^{60}$, however a similar method for the analysis of RBC fatty acids was published by Block et al., which also is described in a patent ${ }^{61 ; 62}$. Hydrolysed erythrocyte membranes were separated by high-speed centrifugation, the supernatant discarded and the remaining cell pellet was transferred into a tube and resuspended in methanolic $\mathrm{BF}_{3}$. The tube was sealed and heated to $100^{\circ} \mathrm{C}$ for $10 \mathrm{~min}$. Under these conditions FAME were mainly generated from membrane glycerophospholipids (GPL), which were subsequently extracted with equal amounts of hexane and water. A CV was provided for the sum of EPA and DHA (omega-3-index) only. Further data describing the accuracy or repeatability of the method or other individual fatty acid contents were not provided. The method was applied in clinical trials and claims were made that the omega-3-index is inversely correlated with the risk for death from coronary heart disease ${ }^{60}$ or the odds-ratio for an acute coronary syndrome ${ }^{61}$.

Araujo et al. evaluated whether $\mathrm{BF}_{3}$ or $\mathrm{BCl}_{3}$ is more suitable to methylate total fatty acids of RBC or serum lipids. Biological samples were mixed with both of the boron trihalides individually and FAME synthesis was generated at $100^{\circ} \mathrm{C}$ for $60 \mathrm{~min}$. The resulting methyl esters were extracted with hexane. Differences in concentrations or fatty acid proportions between both methods were not observed. The repeatability of the method for individual fatty acids was not shown, but an average percentage of total variance of $3.2 \%$ was reported. Furthermore, the effect of adding hexane before or after FAME synthesis was investigated. Significant differences were found in samples with low or high (triacylglycerides) triacylglycerides (TAG) concentrations. Thus, the authors advised to add hexane subsequently to the methylation process.

\section{Plasma GPL}

Glaser et al. published and patented a method for the analysis of GPL fatty acids in plasma ${ }^{63 ; 64}$. The sample preparation was reduced to a 2-step procedure (Fig. 2C). In a first step, plasma proteins were precipitated with methanol and removed by centrifugation together with TAG and cholesteryl ester (CE). In a second step, GPL fatty acids were selectively transmethylated by base catalysis (sodium methoxide) at room temperature. CE, non-esterified fatty acids (NEFA) and sphingomyelins (SP) were not converted to FAME under the conditions applied. FAME were extracted by hexane. Testing intra- and inter assay reproducibility indicated low CV for all analysed fatty acids. A comparison to a reference method for plasma PL showed high correlations for all fatty acids contributing more than $1 \%$ to total fatty acids. The method was used for the analysis of serum samples from 951 children between 2 and 6 years of age. The results of this study are comparable with published results for plasma and serum $\mathrm{PL}^{65-68}$ and might be used as reference values ${ }^{69}$.

\section{Cheek Cells}

McMurchie has proposed cheek cells as biomarker for the dietary fat intake in $1985^{70}$, but its use in studies is limited $^{70-76}$. The main hurdle to overcome is the small sample size, which may limit a proper analysis of fatty acids. In addition, losses of lipid fractions through the chromatographic separation hamper an accurate and reliable fatty acid determination. Recently a method published for the analysis of cheek cell GPL overcame these limitations ${ }^{77}$. Cheek cells were collected with an endocervial brush with or without additional mouth rinse. Cheek cells were separated from the supernatant by centrifugation and the pellet redissolved in methanol. Ultrasound treatment of the cell pellet was necessary to disrupt the cells before eliminating the proteins by centrifugation. GPL fatty acids in the methanolic supernatant were transesterified to FAME by sodium methoxide and hexane used for extraction. Intra- and inter-assay repeatability indicated low CV for all analysed fatty acids in samples with more than 100,000 cells. A comparison of cheek cell sampling with and without mouth rinse showed significant differences in yield, but also without mouth rinse cell numbers were sufficient for analysis. The quantitative and qualitative determination of GPL fatty acids in cheek cells kept over 48 hours at room temperature showed no changes in fatty acid patterns, but losses in fatty acid concentrations. The method was used for the comparison of GPL fatty acid levels between plasma and cheek cell of subjects participating in a healthy lifestyle study. Strong correlations were found for DHA and EPA, and lower correlations for $\mathrm{AA}$, although the $n-3$ fatty acid proportions in cheek cells were much lower then in plasma. This is in accordance to cheek cell PL data published by Hoffman et al. and Laitinen et al. ${ }^{72 ; 75}$. 


\section{Discussion}

This systematic review describes novel methods, which exclude lipid extraction and lipid class separation. These procedures offer advantages over the conventional methods, e.g. lower costs and handling, a higher throughput and reduced equipment and solvent usage. However, different biological compartments have been used for the evaluation of the $n-3$ fatty acid status, such as whole blood, total plasma or RBC lipids or cheek cells. These biological markers may inherent limitations, which are described below. Differences in fatty acid concentrations and composition caused by the choice of specific catalysts $^{58 ; 78}$ or the derivatisation settings applied ${ }^{79}$ are not evaluated in this review.

In general, the results obtained for whole blood lipids correlate with established fatty acid status markers ${ }^{53 ; 54}$. Moreover, the determination of $n-3$ fatty acid levels in capillary whole blood lipids provides a series of advantages: (a) minimal invasive sampling; (b) no venipuncture is required for blood sampling (c); samples can be taken independently to location of a laboratory; d) sample preparation, storage and shipment saves costs; and (e) sample storage requires much less space. However, some limitations have to be considered when using this procedure in clinical trials. It was reported that the treatment of the filter paper with BHT is essential to avoid significantly high losses of DHA, which were significant already after 24 hours $^{80}$. Furthermore, the BHT treatment does not prevent losses of $n$ - 3 LC-PUFA during the long-term storage at room temperature or at $4^{\circ} \mathrm{C}^{59}$. It seems to be necessary to keep samples at $-80^{\circ} \mathrm{C}$, if storage over a long period is required. Furthermore, total plasma lipids represent a mixture of fatty acid moieties, i.e. CE, PL, TAG and NEFA. Hodson et al. estimated that approximately half of all plasma fatty acids can derive from $\mathrm{TAG}^{3}$. Thus, the apparent fatty acid status depends on the postprandial state of the subject. Strict sampling conditions such as overnight fasting can reduce the influence of TAG on the overall fatty acid status of whole blood, but this limits the application in infants.

Analysing RBC total lipids has the advantage that RBC are not immediately influenced by the postprandial state of a subject and therefore might be better suited as fatty acid status marker. The method described for the assessment of the omega-3 index in RBC60;61 relates on the specific FAME synthesis of individual lipid classes. Only free fatty acids, monoand diglycerides, phosphatidylcholine, -serine, -ethanolamine and -inositol are transesterified within the first $10 \mathrm{~min}$ at $100^{\circ} \mathrm{C}^{79}$. A partial transesterification of fatty acids from other RBC lipid fractions, such as SP, CE, or TAG may take place, if time and temperature settings are changed. Therefore, a strict compliance to the analytical procedure is indispensable for reproducible and accurate data.

The analysis of total plasma lipids has the advantage that process steps can be kept to a minimum. The 'open-tube' transesterification procedure allows a semi-automated fatty acid analysis ${ }^{46}$. This has the potential to save preparation time and labour costs and high quantities of samples can be prepared for GC analysis. This also will simplify the execution of large clinical trials with the emphasis on total plasma lipids due to the simple and rapid sample preparation. However, restrictions apply similar to those of whole blood mentioned above.

The advantage of the base catalysed transesterification of plasma GPL, which can be carried out at room temperature, is the high-throughput of samples ( $>50$ per day). The authors claim that the time for the gas chromatographic analysis is the limiting factor for the throughput. In addition, no chromatographic separation is necessary for the specific analysis of plasma GPL. A limitation of the method might be the exclusion of SP, as SFA with $>20$ carbon atoms and C24:1n-9 are mainly incorporated in this fraction. This might change the proportion of other fatty acids, but the proportions of these fatty acids in plasma SP are low and the comparison with plasma PL indicated high correlations for the $n$ - 3 fatty acids. Based on the FAME synthesis and open-tube application, it seems to be possible to automate this procedure for the specific analysis of plasma GPL. Although sampling requires blood collection, the method is well suitable to determine the fatty acid status of individuals in large clinical studies.

Cheek cell sampling is non-invasive, which can be done without trained clinical personal and independently of the location of a laboratory. The major advantage is the higher willingness of individuals to donate cheek cells rather than blood. In addition, cheek cell fatty acid levels are not dependent on the postprandial state of subjects. A limitation of cheek cell sampling could be the insecurity in collecting sufficient amounts of cell material in contrast to defined volumes taken by blood sampling. The contamination of samples with TAG derived from food residues is possible, which affects the determination of cheek cell total lipids. However, analysing GPL fatty acids strongly reduces this impact, but strict sampling procedures are necessary to collect high-quality samples and sufficient cell amounts. The application of cheek cell PL or GPL as $n-3$ fatty acid status markers has been demonstrated ${ }^{70-72 ; 77}$. The method is well suitable for large $n-3$ intervention studies, especially with infants, where invasive sampling is restricted.

\section{Conclusion}

Many new approaches have been developed for the $n-3$ fatty acid status determination. All these methods have strengths and weaknesses and their application need to be carefully considered in order to answer specific questions. It has been shown that the traditional lipid extraction and lipid class separation can be abandoned to save time and costs, which allows analysing larger sample numbers of clinical or epidemiological trials. When successfully validated against dietary intake of $n-3$ fatty acids, this opens new avenues in the area of lipid research, and may push the clarification of potential health benefits of $n-3$ fatty acids.

\section{Acknowledgements}

The authors have no conflicts of interest. Both authors contributed equally to this systematic review.

We gratefully acknowledge the financial support by the Federal Ministry of Education and Research (project number: 
0315680B). Further support by the Commission of the European Communities, within the 7th Framework Programme, NUTRIMENTHE, FP7-212652 is gratefully acknowledged. This manuscript does not necessarily reflect the views of the Commission and in no way anticipates the future policy in this area. B. Koletzko is the recipient of a Freedom to Discover Award of the Bristol-Myers Squibb Foundation, New York, NY.

\section{References}

1. Lattka E, Illig T, Heinrich J, et al. (2010) Do FADS genotypes enhance our knowledge about fatty acid related phenotypes? Clin Nutr 29, 277-287.

2. Fekete K, Marosvolgyi T, Jakobik V, et al. (2009) Methods of assessment of $\mathrm{n}-3$ long-chain polyunsaturated fatty acid status in humans: a systematic review. Am J Clin Nutr 89, 2070S-2084S.

3. Hodson L, Skeaff CM \& Fielding BA (2008) Fatty acid composition of adipose tissue and blood in humans and its use as a biomarker of dietary intake. Prog Lipid Res 47, 348-380.

4. Siguel EN, Chee KM, Gong JX, et al. (1987) Criteria for essential fatty acid deficiency in plasma as assessed by capillary column gas-liquid chromatography. Clin Chem 33, 1869-1873.

5. Al-Turkmani MR, Freedman SD \& Laposata M (2007) Fatty acid alterations and n-3 fatty acid supplementation in cystic fibrosis. Prostaglandins Leukot Essent Fatty Acids 77, 309-318.

6. Min Y, Ghebremeskel K, Lowy C, et al. (2004) Adverse effect of obesity on red cell membrane arachidonic and docosahexaenoic acids in gestational diabetes. Diabetologia 47, 75-81.

7. Rise P, Volpi S, Colombo C, et al. (2010) Whole blood fatty acid analysis with micromethod in cystic fibrosis und pulmonary disease. Journal of Cystic Fibrosis 9, 228-233.

8. Delgado-Noguera MF, Calvache JA \& Bonfill Cosp X (2011) Supplementation with long chain polyunsaturated fatty acids (LCPUFA) to breastfeeding mothers for improving child growth and development. Cochrane Database Syst Rev CD007901.

9. Agostoni C, Buonocore G, Carnielli VP, et al. (2009) Enteral nutrient supply for preterm infants: commentary from the European Society of Paediatric Gastroenterology, Hepatology and Nutrition Committee on Nutrition. J Pediatr Gastroenterol Nutr 50, 85-91.

10. Schulzke SM, Patole SK \& Simmer K (2011) Longchain polyunsaturated fatty acid supplementation in preterm infants. Cochrane Database Syst Rev 2, CD000375.

11. Simmer K, Patole SK \& Rao SC (2008) Longchain polyunsaturated fatty acid supplementation in infants born at term. Cochrane Database Syst Rev CD000376.

12. Carlson SE (2009) Docosahexaenoic acid supplementation in pregnancy and lactation. Am J Clin Nutr 89, 678S-684S.

13. Koletzko B, Lien E, Agostoni C, et al. (2008) The roles of long-chain polyunsaturated fatty acids in pregnancy, lactation and infancy: review of current knowledge and consensus recommendations. J Perinat Med 36, 5-14.

14. Leung BM, Wiens K \& Kaplan BJ (2011) Does prenatal micronutrient supplementation improve children's mental development? A systematic review. BMC Pregnancy Childbirth 11, 12.

15. Raz R \& Gabis L (2009) Essential fatty acids and attentiondeficit-hyperactivity disorder: a systematic review. Dev Med Child Neurol 51, 580-592.

16. Hooper L, Thompson RL, Harrison RA, et al. (2006) Risks and benefits of omega 3 fats for mortality, cardiovascular disease, and cancer: systematic review. BMJ 332, 752-760.
17. von Schacky C \& Harris WS (2007) Cardiovascular benefits of omega-3 fatty acids. Cardiovasc Res 73, 310-315.

18. Dewey A, Baughan C, Dean T, et al. (2007) Eicosapentaenoic acid (EPA, an omega-3 fatty acid from fish oils) for the treatment of cancer cachexia. Cochrane Database Syst Rev CD004597.

19. Funahashi H, Satake M, Hasan S, et al. (2008) Opposing effects of n-6 and n-3 polyunsaturated fatty acids on pancreatic cancer growth. Pancreas 36, 353-362.

20. Kuriki K, Hirose K, Wakai K, et al. (2007) Breast cancer risk and erythrocyte compositions of n-3 highly unsaturated fatty acids in Japanese. Int J Cancer 121, 377-385.

21. Leung BMY \& Kaplan BJ (2009) Perinatal Depression: Prevalence, Risks, and the Nutrition Link-A Review of the Literature. Journal of the American Dietetic Association 109, 1566-1575.

22. Lin P-Y, Huang S-Y \& Su K-P (2011) A Meta-Analytic Review of Polyunsaturated Fatty Acid Compositions in Patients with Depression. Biological Psychiatry 68, 140-147.

23. Montgomery P \& Richardson AJ (2008) Omega-3 fatty acids for bipolar disorder. Cochrane Database Syst Rev CD005169.

24. Ramakrishnan U (2011) Fatty acid status and maternal mental health. Maternal, Child Nutrition 7, 99-111.

25. Turner D, Shah PS, Steinhart AH, et al. (2011) Maintenance of remission in inflammatory bowel disease using omega-3 fatty acids (fish oil): a systematic review and meta-analyses. Inflamm Bowel Dis 17, 336-345.

26. Thien FCK, De Luca S, Woods RK, et al. (2011) Cochrane Review: Dietary marine fatty acids (fish oil) for asthma in adults and children. Evidence-Based Child Health: A Cochrane Review Journal 6, 984-1012.

27. McKarney C, Everard M \& N'Diaye T (2007) Omega-3 fatty acids (from fish oils) for cystic fibrosis. Cochrane Database Syst Rev CD002201.

28. Cederholm T \& Palmblad J (2011) Are omega-3 fatty acids options for prevention and treatment of cognitive decline and dementia? Current Opinion in Clinical Nutrition, Metabolic Care 13, 150-155, 110.1097/MCO.1090b1013e328335c328340b.

29. Milte CM, Sinn N \& Howe PR (2009) Polyunsaturated fatty acid status in attention deficit hyperactivity disorder, depression, and Alzheimer's disease: towards an omega-3 index for mental health? Nutr Rev 67, 573-590.

30. Lepage G \& Roy CC (1986) Direct transesterification of all classes of lipids in a one-step reaction. J Lipid Res 27, 114-120.

31. Bligh EG \& Dyer WJ (1959) A rapid method of total lipid extraction and purification. Can J Biochem Physiol 37, 911-917.

32. Folch J, Lees M \& Sloane Stanley GH (1957) A simple method for the isolation and purification of total lipides from animal tissues. J Biol Chem 226, 497-509.

33. Rose HG \& Oklander M (1965) Improved Procedure for the Extraction of Lipids from Human Erythrocytes. J Lipid Res $\mathbf{6}$, 428-431.

34. Carnielli VP, Pederzini F, Vittorangeli R, et al. (1996) Plasma and red blood cell fatty acid of very low birth weight infants fed exclusively with expressed preterm human milk. Pediatr Res 39, 671-679.

35. Skipski VP, Peterson RF \& Barclay M (1964) Quantitative analysis of phospholipids by thin-layer chromatography. Biochem J 90, 374-378.

36. Agren JJ, Julkunen A \& Penttila I (1992) Rapid separation of serum lipids for fatty acid analysis by a single aminopropyl column. J Lipid Res 33, 1871-1876.

37. Burdge GC, Wright P, Jones AE, et al. (2000) A method for separation of phosphatidylcholine, triacylglycerol, 
non-esterified fatty acids and cholesterol esters from plasma by solid-phase extraction. BrJ Nutr 84, 781-787.

38. Hamilton JG \& Comai K (1988) Rapid separation of neutral lipids, free fatty acids and polar lipids using prepacked silica Sep-Pak columns. Lipids 23, 1146-1149.

39. Kaluzny MA, Duncan LA, Merritt MV, et al. (1985) Rapid separation of lipid classes in high yield and purity using bonded phase columns. J Lipid Res 26, 135-140.

40. Vorbeck ML, Mattick LR, Lee FA, et al. (1961) Preparation of Methyl Esters of Fatty Acids for Gas-Liquid Chromatography. Quantitative Comparison of Methylation Techniques. Analytical Chemistry 33, 1512-1514.

41. Dodds ED, McCoy MR, Rea LD, et al. (2005) Gas chromatographic quantification of fatty acid methyl esters: flame ionization detection vs. electron impact mass spectrometry. Lipids 40, 419-428.

42. Lepage G, Levy E, Ronco N, et al. (1989) Direct transesterification of plasma fatty acids for the diagnosis of essential fatty acid deficiency in cystic fibrosis. J Lipid Res 30, 1483-1490.

43. Martinez M, Mougan I, Roig M, et al. (1994) Blood polyunsaturated fatty acids in patients with peroxisomal disorders. A multicenter study. Lipids 29, 273-280.

44. Tiangson CLP, Gavino VC, Gavino G, et al. (2003) Docosahexaenoic acid level of the breast milk of some Filipino women. International Journal of Food Sciences and Nutrition 54, 379-386.

45. Dacremont G \& Vincent G (1995) Assay of plasmalogens and polyunsaturated fatty acids (PUFA) in erythrocytes and fibroblasts. J Inherit Metab Dis 18, Suppl. 1, 84-89.

46. Masood A, Stark KD \& Salem N Jr (2005) A simplified and efficient method for the analysis of fatty acid methyl esters suitable for large clinical studies. J Lipid Res 46, 2299-2305.

47. Masood M \& Salem N (2008) High-Throughput Analysis of Plasma Fatty Acid Methyl Esters Employing Robotic Transesterification and Fast Gas Chromatography. Lipids 43, 171-180.

48. Garg ML, Leitch J, Blake RJ, et al. (2006) Long-chain n-3 polyunsaturated fatty acid incorporation into human atrium following fish oil supplementation. Lipids 41, 1127-1132.

49. Akoto L, Vreuls RJ, Irth H, et al. (2008) Fatty acid profiling of raw human plasma and whole blood using direct thermal desorption combined with gas chromatography-mass spectrometry. J Chromatogr A 1186, 365-371.

50. Glaser C, Demmelmair H \& Koletzko B (2010) Highthroughput analysis of total plasma fatty acid composition with direct in situ transesterification. PLoS One 5, e12045.

51. Takemoto Y, Suzuki Y, Horibe R, et al. (2003) Gas chromatography/mass spectrometry analysis of very long chain fatty acids, docosahexaenoic acid, phytanic acid and plasmalogen for the screening of peroxisomal disorders. Brain Dev 25, 481-487.

52. Armstrong JM, Metherel AH \& Stark KD (2008) Direct microwave transesterification of fingertip prick blood samples for fatty acid determinations. Lipids 43, 187-196.

53. Bailey-Hall E, Nelson EB \& Ryan AS (2008) Validation of a rapid measure of blood PUFA levels in humans. Lipids $\mathbf{4 3}$, 181-186.

54. Marangoni F, Colombo C \& Galli C (2005) A method for the direct evaluation of the fatty acid status in a drop of blood from a fingertip in humans. World Rev Nutr Diet 94, 139-143.

55. Agostoni C, Marangoni F, Stival G, et al. (2008) Whole blood fatty acid composition differs in term versus mildly preterm infants: small versus matched appropriate for gestational age. Pediatr Res 64, 298-302.

56. Agostoni C, Riva E, Giovannini M, et al. (2008) Maternal smoking habits are associated with differences in infants' long-chain polyunsaturated fatty acids in whole blood: a case-control study. Arch Dis Child 93, 414-418.

57. Ryan AS \& Nelson EB (2008) Assessing the effect of docosahexaenoic acid on cognitive functions in healthy, preschool children: a randomized, placebo-controlled, double-blind study. Clin Pediatr (Phila) 47, 355-362.

58. Bicalho B, David F, Rumplel K, et al. (2008) Creating a fatty acid methyl ester database for lipid profiling in a single drop of human blood using high resolution capillary gas chromatography and mass spectrometry. JChromatogr A 1211, 120-128.

59. Min Y, Ghebremeskel K, Geppert J, et al. (2011) Effect of storage temperature and length on fatty acid composition of fingertip blood collected on filter paper. Prostaglandins Leukot Essent Fatty Acids 84, 13-18.

60. Harris WS \& Von Schacky C (2004) The Omega-3 Index: a new risk factor for death from coronary heart disease? Prev Med 39, 212-220.

61. Block RC, Harris WS, Reid KJ, et al. (2008) EPA and DHA in blood cell membranes from acute coronary syndrome patients and controls. Atherosclerosis 197, 821-828.

62. Shearer CS, Pottala JV \& Harris WS (2010) Fatty acid pattern analysis for predicting acute coronary syndrome 17, Sanford Research/USD

63. Glaser C, Demmelmair H \& Koletzko B (2010) High-throughput analysis of fatty acid composition of plasma glycerophospholipids. J Lipid Res 51, 216-221.

64. Glaser CD, H \& Koletzko B (2009) High Throughput method for analyzing the fatty acid composition in palsma phosphoglycerides [LUDWIG-MAXIMILIANS-UNIVERSITÄT, editor]. Germany.

65. Decsi T \& Koletzko B (1994) Fatty acid composition of plasma lipid classes in healthy subjects from birth to young adulthood. Eur J Pediatr 153, 520-525.

66. Gronowitz E, Mellstrom D \& Strandvik B (2006) Serum phospholipid fatty acid pattern is associated with bone mineral density in children, but not adults, with cystic fibrosis. $\mathrm{BrJ}$ Nutr 95, 1159-1165.

67. Guerra A, Demmelmair H, Toschke AM, et al. (2007) Threeyear tracking of fatty acid composition of plasma phospholipids in healthy children. Ann Nutr Metab 51, 433-438.

68. Hoyos C, Almqvist C, Garden F, et al. (2008) Effect of omega 3 and omega 6 fatty acid intakes from diet and supplements on plasma fatty acid levels in the first 3 years of life. Asia Pac J Clin Nutr 17, 552-557.

69. Glaser C, Demmelmair H, Sausenthaler S, et al. (2010) Fatty acid composition of serum glycerophospholipids in children. J Pediatr 157, 826-831 e821.

70. McMurchie EJ, Margetts BM, Beilin LJ, et al. (1984) Dietaryinduced changes in the fatty acid composition of human cheek cell phospholipids: correlation with changes in the dietary polyunsaturated/saturated fat ratio. Am J Clin Nutr 39, 975-980.

71. Connor SL, Zhu N, Anderson GJ, et al. (2000) Cheek cell phospholipids in human infants: a marker of docosahexaenoic and arachidonic acids in the diet, plasma, and red blood cells. Am J Clin Nutr 71, 21-27.

72. Hoffman DR, Birch EE, Birch DG, et al. (1999) Fatty acid profile of buccal cheek cell phospholipids as an index for dietary intake of docosahexaenoic acid in preterm infants. Lipids 34, 337-342.

73. Kirby A, Woodward A, Jackson S, et al. (2010) A doubleblind, placebo-controlled study investigating the effects of omega-3 supplementation in children aged 8-10 years from a mainstream school population. Res Dev Disabil 31, $718-730$. 
74. Koletzko B, Knoppke B, von Schenck U, et al. (1999) Noninvasive assessment of essential fatty acid status in preterm infants by buccal mucosal cell phospholipid analysis. J Pediatr Gastroenterol Nutr 29, 467-474.

75. Laitinen K, Sallinen J, Linderborg K, et al. (2006) Serum, cheek cell and breast milk fatty acid compositions in infants with atopic and non-atopic eczema. Clin Exp Allergy 36, $166-173$.

76. Sampugna J, Light L, Enig MG, et al. (1988) Cheek cell fatty acids as indicators of dietary lipids in humans. Lipids $\mathbf{2 3}$, 131-136.

77. Klingler M, Demmelmair H, Koletzko B, et al. (2011) Fatty Acid status determination by cheek cell sampling combined with methanol-based ultrasound extraction of glycerophospholipids. Lipids 46, 981-990.

78. Kohn G, van der Ploeg P, Mobius M, et al. (1996) Influence of the derivatization procedure on the results of the gaschromatographic fatty acid analysis of human milk and infant formulae. Z Ernabrungswiss 35, 226-234.

79. Morrison WR \& Smith LM (1964) Preparation of Fatty Acid Methyl Esters and Dimethylacetals from Lipids with Boron Fluoride-Methanol. J Lipid Res 5, 600-608.

80. Ichihara Ki, Waku K, Yamaguchi C, et al. (2002) A convenient method for determination of the C(20-22) PUFA composition of glycerolipids in blood and breast milk. Lipids 37, 523-526. 